\title{
Supramolecular Control of Charge Transport in Molecular Wires
}

\author{
F. C. Grozema, C. Houarner-Rassin, P. Prins, L. D. A. Siebbeles, and H. L. Anderson
}

\section{Table of Contents:}

Scheme S1: Synthesis of polymer 1

page $\mathrm{S} 1$

Synthetic Experimental Details

page S2-S3

Figures S1 and S2: UV-vis-NIR Titrations of Polymer 1 with Bipy
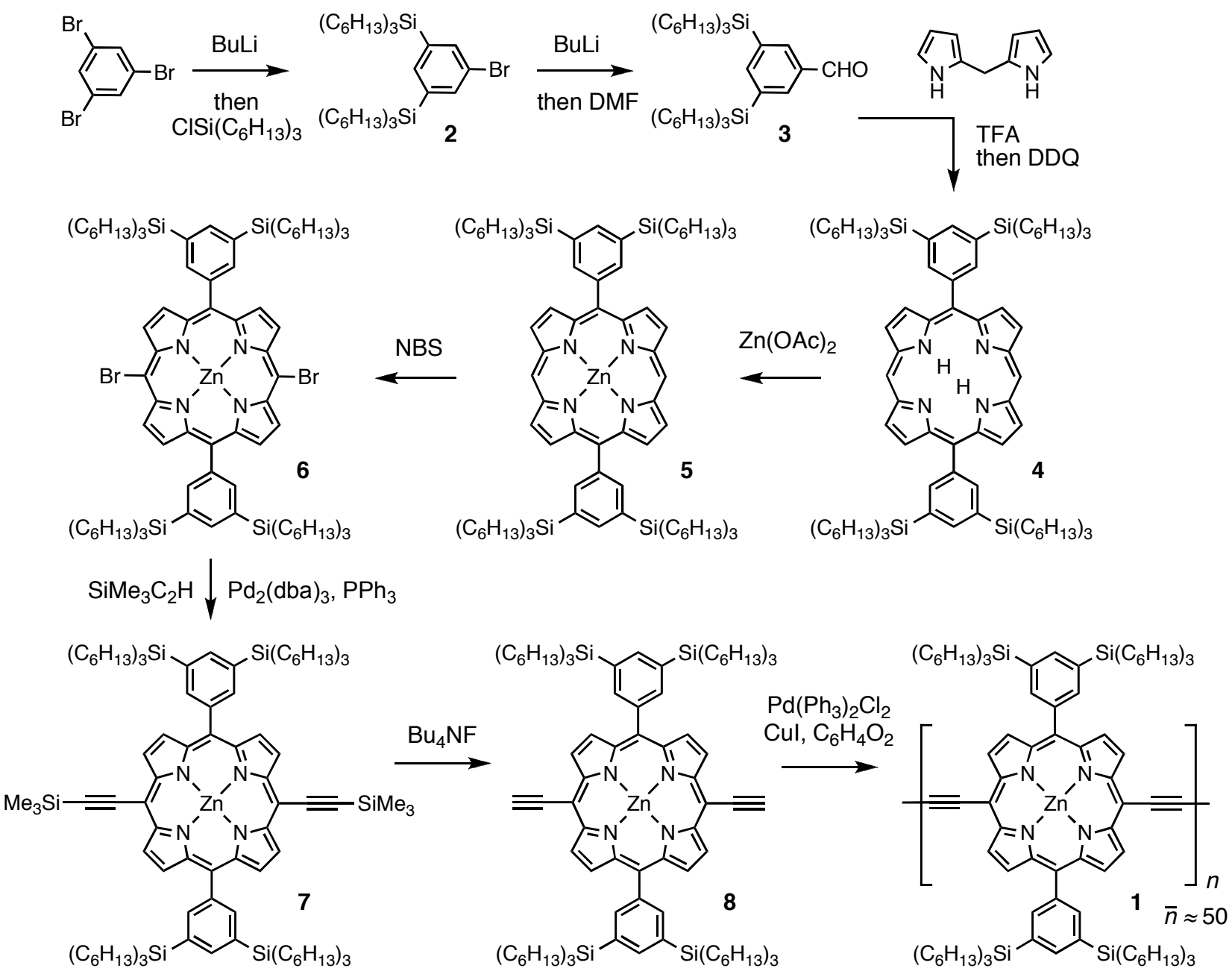

Scheme S1: Synthesis of polymer 1. This new trihexylsilyl-solubilized polymer was synthesized specially so as to achieve high solubility in nonpolar solvents for the time-resolved microwave conductivity study reported in this Communication. The other porphyrin polymers synthesized previously in Oxford had insufficient solubility in benzene, particularly as their double-strand Bipy complexes. 


\section{Synthetic Experimental Details}

\section{3,5-Bis(trihexylsilyl)bromobenzene 2}

To a stirring solution of 1,3,5-tribromobenzene $(5.00 \mathrm{~g}, 15.8 \mathrm{mmol})$ in $\mathrm{Et}_{2} \mathrm{O}(125 \mathrm{~mL})$ at $-78^{\circ} \mathrm{C}$, was added $n$ butyl lithium $(1.6 \mathrm{M}$ in hexane, $20.8 \mathrm{~mL}, 33.3 \mathrm{mmol})$ dropwise, under inert atmosphere. The solution was stirred for 90 min before adding trihexylsilylchloride $(13.5 \mathrm{~mL}, 34.9 \mathrm{mmol})$ dropwise via a syringe. The solution was allowed to warm to room temperature. After stirring for another $90 \mathrm{~min}$, the reaction mixture was washed with water, dried over $\mathrm{MgSO}_{4}$ and filtered. The solution was concentrated and passed through a silica plug with Petroleum Ether. The solvent was removed to give $10.6 \mathrm{~g}$ of a $3: 1$ mixture of 3,5-bis(trihexylsilyl)bromobenzene 2 and 1,3,5-tris(trihexylsilyl)benzene. This crude product was used without further purification.

\section{3,5-Bis(trihexylsilyl)benzaldehyde 3}

$n$-Butyl lithium (1.6 M in hexane, $27.5 \mathrm{~mL}, 44 \mathrm{mmol}$ ) was added dropwise to a solution of 3,5bis(trihexylsilyl)bromobenzene $2(10.6 \mathrm{~g}, 14.7 \mathrm{mmol})$ in dry $\mathrm{Et}_{2} \mathrm{O}(70 \mathrm{~mL})$ under $\mathrm{N}_{2}$ at $0^{\circ} \mathrm{C}$. The solution was stirred at this temperature for $30 \mathrm{~min}$ and then at room temperature for $90 \mathrm{~min}$. $\mathrm{N}, \mathrm{N}$-Dimethylformamide (5.3 $\mathrm{mL}, 70 \mathrm{mmol}$ ) was added and the mixture was stirred for $1 \mathrm{hr}$. Aqueous saturated ammonium chloride solution $(100 \mathrm{~mL})$ was added and the organic layer was separated. The aqueous layer was extracted with $\mathrm{Et}_{2} \mathrm{O}$. The combined organic layer was washed with an aqueous solution of $\mathrm{NaHCO}_{3}$ and with water, dried over $\mathrm{MgSO}_{4}$ and filtered. The crude product was purified by column chromatography on silica gel eluting with a gradients of $\mathrm{CH}_{2} \mathrm{Cl}_{2}$ and $40-60^{\circ} \mathrm{C}$ petroleum ether (starting from $0 \%$ to $10 \% \mathrm{CH}_{2} \mathrm{Cl}_{2}$ ). The solvent was removed to give 3,5-bis(trihexylsilyl)benzaldehyde $3\left(4.3 \mathrm{~g}, 41 \%\right.$ over two steps) as a yellow oil. ${ }^{1} \mathrm{H}$ NMR (400 MHz, $\left.\mathrm{CDCl}_{3}\right): \delta 10.04(\mathrm{~s}, 1 \mathrm{H}), 7.93(\mathrm{~s}, 2 \mathrm{H}), 7.85(\mathrm{~s}, 1 \mathrm{H}), 0.81-1.31(\mathrm{~m}, 78 \mathrm{H}) ;{ }^{13} \mathrm{C} \mathrm{NMR}(100 \mathrm{MHz}$, $\left.\mathrm{CDCl}_{3}\right): \delta 193.5,146.1$ 138.3, 135.9, 134.6, 33.4, 31.5, 23.8, 22.6, 14.1, 12.3; $\mathrm{m} / \mathrm{z}$ (Tof MS ESI) 693.58 $\left([\mathrm{M}+\mathrm{Na}]^{+}, \mathrm{C}_{43} \mathrm{H}_{82} \mathrm{NaOSi}_{2}\right.$, requires 693.58).

\subsubsection{5,15-Bis[3,5(trihexylsilyl)phenyl]porphyrin 4}

3,5-Bis(trihexylsilyl)benzaldehyde $3(2.55 \mathrm{~g}, 3.8 \mathrm{mmol})$ and dipyrromethane $(0.56 \mathrm{~g}, 3.8 \mathrm{mmol})$ were dissolved in $\mathrm{CH}_{2} \mathrm{Cl}_{2}(700 \mathrm{~mL})$. The solution was saturated with nitrogen, then TFA $(0.5 \mathrm{~mL}, 7.6 \mathrm{mmol})$ was added and the mixture was stirring for $3 \mathrm{hrs}$ in the dark. Then, DDQ $(1.5 \mathrm{~g}, 6.6 \mathrm{mmol})$ was added and the mixture was stirred for a further 20 min. Finally, triethylamine $(3.8 \mathrm{~mL})$ was added to quench the acid. The solution was concentrated and pass through a short silica plug eluting with a mixture of $40-60^{\circ} \mathrm{C}$ petroleum ether and $\mathrm{CH}_{2} \mathrm{Cl}_{2}$ (80/20). The solvent was removed to give the free base porphyrin $4(1.63 \mathrm{~g}, 29 \%)$ as red crystals. ${ }^{1} \mathrm{H}$ NMR $\left(400 \mathrm{MHz}, \mathrm{CDCl}_{3}\right): \delta 10.35(\mathrm{~s}, 2 \mathrm{H}), 9.40(\mathrm{~d}, J=4.5,4 \mathrm{H}), 9.09(\mathrm{~d}, J=4.5,4 \mathrm{H}), 8.37(\mathrm{~s}, 4 \mathrm{H})$, $8.02(\mathrm{~s}, 2 \mathrm{H}), 0.87-1.52(\mathrm{~m}, 156 \mathrm{H}),-3.03(\mathrm{~s}, 2 \mathrm{H}) ;{ }^{13} \mathrm{C}$ NMR $\left(100 \mathrm{MHz}, \mathrm{CDCl}_{3}\right): \delta 147.5,145.1,141.7,139.15$, $139.2,135.4,131.5,131.2,120.3,105.2,33.6,31.7,24.1,22.7,14.2,12.7 ; \mathrm{UV}\left(\mathrm{CH}_{2} \mathrm{Cl}_{2}\right): \lambda_{\max }(\log \varepsilon)=410$ (5.81), 505 (4.37), 541 (3.98), 577 (3.86), 632 (3.45); MS (MALDI-TOF) m/z $1598.36\left(\mathrm{M}^{+}, \mathrm{C}_{104} \mathrm{H}_{174} \mathrm{~N}_{4} \mathrm{Si}_{4}\right.$ requires 1591.28).

\section{[5,15-Bis(3,5(trihexylsilyl)phenyl)porphyrinato]zinc(II) 5}

A solution of $\mathrm{Zn}(\mathrm{OAc})_{2} \cdot 2 \mathrm{H}_{2} \mathrm{O}(0.92 \mathrm{~g}, 4.2 \mathrm{mmol})$ in $\mathrm{MeOH}(10 \mathrm{~mL})$ and added to a solution of $5,15-$ bis[3,5(trihexylsilyl)phenyl]porphyrin $4(1.33 \mathrm{~g}, 0.83 \mathrm{mmol})$ in $\mathrm{CHCl}_{3}(70 \mathrm{~mL})$. The mixture was stirred at room temperature for $3.5 \mathrm{hrs}$, then evaporated and passed through a short silica plug, eluting with a mixture of $40-60^{\circ} \mathrm{C}$ petroleum ether and $\mathrm{CH}_{2} \mathrm{Cl}_{2}(80 / 20)$. The solvent was removed to give the zinc porphyrin $5(1.39$ g, $99 \%)$ as pink crystals. ${ }^{1} \mathrm{H}$ NMR $\left(400 \mathrm{MHz}, \mathrm{CDCl}_{3}\right): \delta 10.39(\mathrm{~s}, 2 \mathrm{H}), 9.47(\mathrm{~d}, \mathrm{~J}=4.5,4 \mathrm{H}), 9.17(\mathrm{~d}, \mathrm{~J}=4.5$, $4 \mathrm{H}), \quad 8.37(\mathrm{~s}, 4 \mathrm{H}), 8.03(\mathrm{~s}, 2 \mathrm{H}), 0.82-1.52(\mathrm{~m}, 156 \mathrm{H}) ;{ }^{13} \mathrm{C}$ NMR $\left(100 \mathrm{MHz} \mathrm{CDCl}_{3}\right): \delta 150.5,149.5,140.9$, 140.7, 139.1, 134.9, 132.7, 131.7, 121.4, 106.2, 33.6, 31.7, 24.1, 22.7, 14.2, 12.7; UV $\left(\mathrm{CH}_{2} \mathrm{Cl}_{2}\right): \lambda_{\max }(\log \varepsilon)$ = 422 (5.74), 553 (4.46), 590 (3.90); MS (MALDI-TOF) m/z $1653.71\left(\mathrm{M}^{+}, \mathrm{C}_{104} \mathrm{H}_{172} \mathrm{~N}_{4} \mathrm{Si}_{4} \mathrm{Zn}\right.$ requires 1653.19). 


\section{[5,15-Bis(3,5(trihexylsilyl)phenyl)-10,20-dibromoporphyrinato]zinc(II) 6}

A solution of $N$-bromosuccinimide $(0.11 \mathrm{~g}, 0.6 \mathrm{mmol})$ in $\mathrm{CHCl}_{3}(10 \mathrm{~mL})$ was added to a solution of porphyrin $5(0.5 \mathrm{~g}, 0.3 \mathrm{mmol})$ in pyridine $(0.2 \mathrm{~mL})$ and $\mathrm{CHCl}_{3}(14 \mathrm{~mL})$. The reaction mixture was stirred at room temperature for $15 \mathrm{~min}$ before adding acetone $(0.3 \mathrm{~mL})$ to quenched excess of NBS. The solution was concentrated and pass through a short silica plug eluting with a mixture of $40-60^{\circ} \mathrm{C}$ petroleum ether and $\mathrm{CH}_{2} \mathrm{Cl}_{2}(80 / 20)$. The solvent was removed to give the dibromoporphyrin $6(0.54 \mathrm{~g}, 98 \%)$ as purple crystals. ${ }^{1} \mathrm{H}$ NMR $\left(400 \mathrm{MHz}, \mathrm{CDCl}_{3}\right): \delta 9.74(\mathrm{~d}, J=4.8,4 \mathrm{H}), 8.95(\mathrm{~d}, \mathrm{~J}=4.8,4 \mathrm{H}), 8.25(\mathrm{~s}, 4 \mathrm{H}), 8.01(\mathrm{~s}, 2 \mathrm{H}), 0.87-1.51$ $(\mathrm{m}, 156 \mathrm{H}) ;{ }^{13} \mathrm{C}$ NMR $\left(100 \mathrm{MHz}, \mathrm{CDCl}_{3}\right): \delta 151.3,150.2,140.6,140.2,139.1,135.1,133.8,133.2,123.7$, 105.3, 33.6, 32.0, 24.1, 22.7, 14.2, 12.7; UV $\left(\mathrm{CH}_{2} \mathrm{Cl}_{2}\right): \lambda_{\max }(\log \varepsilon)=428$ (5.81), 558 (4.40), 597 (3.96); MS (MALDI-TOF) $m / z 1818.07\left(\mathrm{M}^{+}, \mathrm{C}_{104} \mathrm{H}_{170} \mathrm{Br}_{2} \mathrm{~N}_{4} \mathrm{Si}_{4} \mathrm{Zn}\right.$ requires 1809.02).

\section{[5,15-Bis(3,5(trihexylsilyl)phenyl)-10,20-bis((trimethylsilyl)ethynyl)porphyrinato] zinc(II) 7}

A solution of porphyrin $6(0.54 \mathrm{~g}, 0.3 \mathrm{mmol})$ was dissolved in a mixture of toluene $(25 \mathrm{~mL})$ and triethylamine $(22 \mathrm{~mL})$. The solution was saturated with nitrogen before adding tris-(dibenzylideneacetone)-di-palladium(0) $(0.036 \mathrm{~g}, 0.3 \mathrm{mmol}), \mathrm{PPh}_{3}(0.08 \mathrm{~g}, 0.3 \mathrm{mmol}), \mathrm{Cul}(0.03 \mathrm{~g}, 0.15 \mathrm{mmol})$ and trimethylsilylacetylene $(0.13 \mathrm{~mL}$, $0.9 \mathrm{mmol}$ ). The solution was stirred at $50^{\circ} \mathrm{C}$ for $2 \mathrm{hrs}$. The product was purified by column chromatography on silica gel eluting with increasing gradients of $\mathrm{CH}_{2} \mathrm{Cl}_{2}$ in $40-60^{\circ} \mathrm{C}$ petroleum ether (starting from $2 \%$ to $5 \%$ of $\left.\mathrm{CH}_{2} \mathrm{Cl}_{2}\right)$ to yield porphyrin 7 as green crystals $(0.465 \mathrm{~g}, 83 \%) .{ }^{1} \mathrm{H}$ NMR $\left(400 \mathrm{MHz}, \mathrm{CDCl}_{3}\right): \delta 9.70(\mathrm{~d}, J=$ $4.5,4 \mathrm{H}), 8.92(\mathrm{~d}, \mathrm{~J}=4.5,4 \mathrm{H}), 8.26(\mathrm{~s}, 4 \mathrm{H}), 8.00(\mathrm{~s}, 2 \mathrm{H}), 0.88-1.50(\mathrm{~m}, 156 \mathrm{H}), 0.60(\mathrm{~s}, 18 \mathrm{H}) .{ }^{13} \mathrm{C}$ NMR $(100$ $\left.\mathrm{MHz}, \mathrm{CDCl}_{3}\right): \delta 152.2,150.6,140.5,140.2,139.2,135.0,133.0,131.2,123.9,107.4,101.8,101.4,33.6$, 31.7, 24.1, 22.7, 14.2, 12.7, 0.30. UV $\left(\mathrm{CH}_{2} \mathrm{Cl}_{2}\right): \lambda_{\max }(\log \varepsilon)=436$ (5.82), 445 (5.67), 577 (4.33), 624 (4.68). MS (MALDI-TOF) $\mathrm{m} / \mathrm{z} 1848.86\left(\mathrm{M}^{+}, \mathrm{C}_{114} \mathrm{H}_{188} \mathrm{~N}_{4} \mathrm{Si}_{6} \mathrm{Zn}\right.$ requires 1845.27).

\section{[5,15-Bis(3,5(trihexylsilyl)phenyl)-10,20-bis(ethynyl)porphyrinato]zinc(II) 8}

TBAF (1.0 M in THF, $0.2 \mathrm{~mL}, 0.17 \mathrm{mmol})$ was added to a solution of porphyrin $7(0.130 \mathrm{~g}, 0.07 \mathrm{mmol})$ in $\mathrm{CH}_{2} \mathrm{Cl}_{2}(15 \mathrm{~mL})$. After $30 \mathrm{~min}$, anhydrous $\mathrm{CaCl}_{2}(100 \mathrm{mg})$ was added and the crude product was passed trough a short silica plug eluting with a mixture of $40-60^{\circ} \mathrm{C}$ petroleum ether and $\mathrm{CH}_{2} \mathrm{Cl}_{2}(80 / 20)$. Further chromatography $\left(40-60^{\circ} \mathrm{C}\right.$ petroleum ether $/ \mathrm{CH}_{2} \mathrm{Cl}_{2}$ 90/10) yielded pure porphyrin 8 as a green solid $(0.11 \mathrm{~g}$, $96 \%$ ). ${ }^{1} \mathrm{H}$ NMR $\left(400 \mathrm{MHz}, \mathrm{CDCl}_{3}\right): \delta 9.75(\mathrm{~d}, J=4.8,4 \mathrm{H}), 8.96(\mathrm{~d}, J=4.8,4 \mathrm{H}), 8.27(\mathrm{~s}, 4 \mathrm{H}), 8.01(\mathrm{~s}, 2 \mathrm{H})$, $4.19(\mathrm{~s}, 2 \mathrm{H}), 0.86-1.50(\mathrm{~m}, 156 \mathrm{H}) ;{ }^{13} \mathrm{C}$ NMR $\left(100 \mathrm{MHz}, \mathrm{CDCl}_{3}\right): \delta 152.3,150.7,140.6,140.2,139.2,135.1$, 131.2, 123.9, 100.1, 85.9, 83.9, 33.6, 31.7, 24.1, 22.7, 14.2, 12.7, 0.30; UV $\left(\mathrm{CH}_{2} \mathrm{Cl}_{2}\right): \lambda_{\max }(\log \varepsilon) 430(5.53)$, 438 (5.47), 568 (4.23), 612 (4.26); MS (MALDI-TOF) m/z $1703.02\left(\mathrm{M}^{+}, \mathrm{C}_{108} \mathrm{H}_{172} \mathrm{~N}_{4} \mathrm{Si}_{4} \mathrm{Zn}\right.$ requires 1701.19).

\section{Porphyrin polymer 1}

1,4-Benzoquinone (6.4 mg, $0.036 \mathrm{mmol})$, copper(I) iodide $(2.7 \mathrm{mg}, 0.014 \mathrm{mmol})$, and $\mathrm{Pd}\left(\mathrm{PPh}_{3}\right)_{2} \mathrm{Cl}_{2}(1.0 \mathrm{mg}$, $0.0014 \mathrm{mmol})$ were loaded into a flask. The vessel was evacuated and refilled with argon. Toluene $(4 \mathrm{~mL})$ and diisopropylamine $(2 \mathrm{~mL})$ were added to the flask. Lastly, a solution of porphyin 8 (80 $\mathrm{mg}, 0.047 \mathrm{mmol})$ in toluene $(5 \mathrm{~mL})$ was added, and the mixture was stirred at $50^{\circ} \mathrm{C}$ for $2.5 \mathrm{hrs}$. The mixture was treated with methanol $(20 \mathrm{~mL})$ and the precipitate was separated by centrifugation (1500 rpm, $10 \mathrm{~min})$. The precipitate was resuspended and centrifuged twice with methanol. Then the polymer was dissolved in a mixture of toluene and THF (1:1), centrifuged (1700 rpm, $10 \mathrm{~min}$ ), decanted and centrifuged again to remove all insoluble material. The polymer solution was concentrated to a minimum and then precipitated into EtOH, centrifuged and dried under the vacuum, to yield polymer 1 as a black solid (85 mg, 71\%). ${ }^{1} \mathrm{H}$ NMR (400 $\left.\mathrm{MHz}_{1} \mathrm{CDCl}_{3}\right): \delta 9.90(\mathrm{~s}, 4 \mathrm{H}), 8.96(\mathrm{~s}, 4 \mathrm{H}), 8.33(\mathrm{~s}, 4 \mathrm{H}), 8.03(\mathrm{~s}, 2 \mathrm{H}), 0.86-1.55(\mathrm{~m}, 156 \mathrm{H}) ; \mathrm{UV}\left(\mathrm{CHCl}_{3}\right): \lambda_{\max }$ $(\log \varepsilon) 468$ (5.01), 780 (4.83). Elemental analysis calcd (\%) for $\mathrm{C}_{108} \mathrm{H}_{170} \mathrm{~N}_{4} \mathrm{Si}_{4} \mathrm{Zn}$ : C 76.20, H 10.07, N 3.29; found C 76.19, H 10.03, N 2.89. GPC (THF; Polymer Laboratories Plgel $5 \mu \mathrm{m}$ MIXED-D column): $M_{\mathrm{n}}=$ 83,$700 ; M_{\mathrm{w}}=15,7000$ (corresponding to a number-average degree of polymerization of 50 repeat units).

These polymerization conditions are derived from those of: Williams, V. E.; Swager, T. M. J. Polym. Sci.: Part A: Polym. Chem. 2000, 38, 4669-4676. 


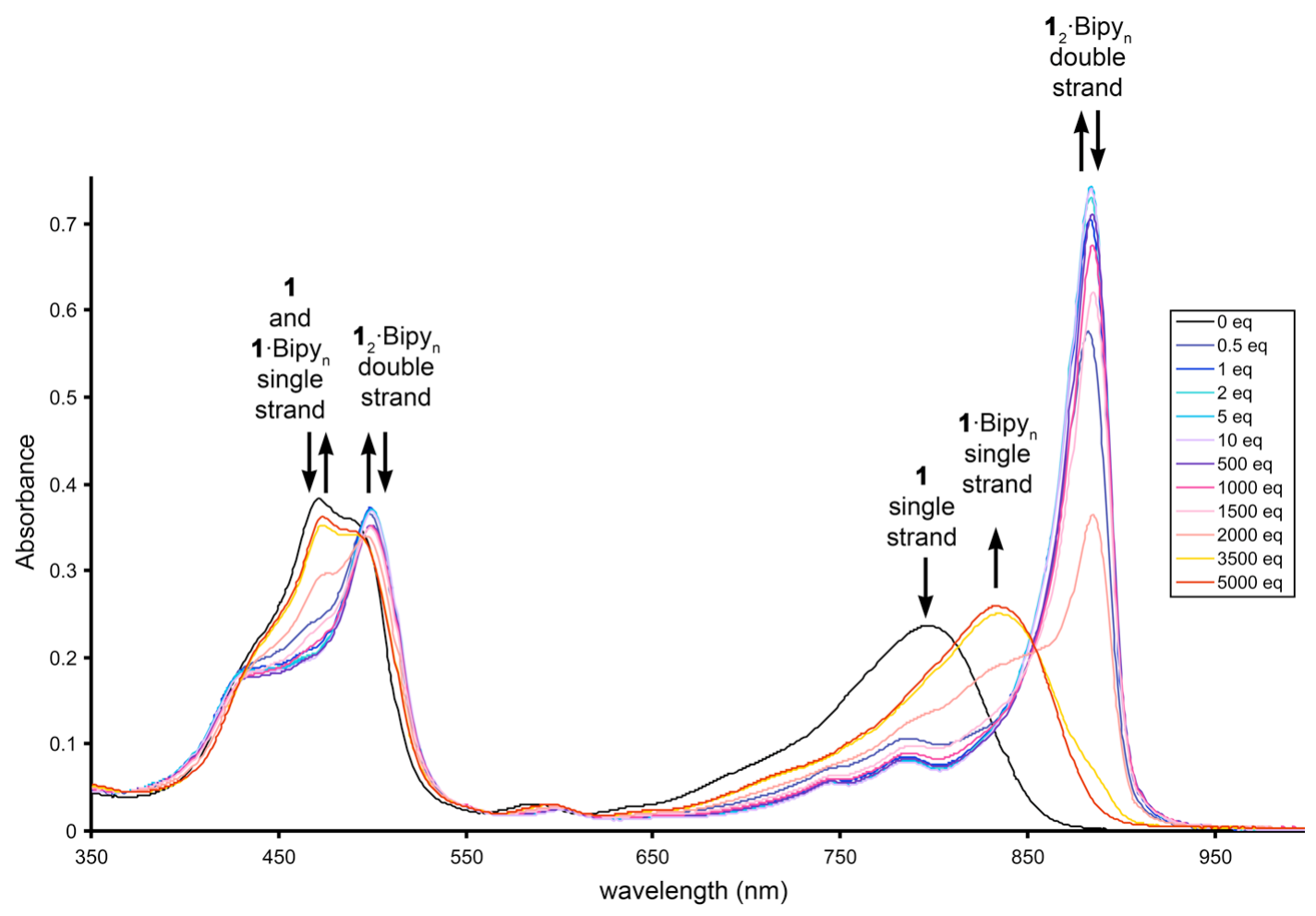

Figure S1: UV-vis-NIR Titration of Polymer 1 with Bipy in benzene; [1] = $4.8 \mu \mathrm{M}$ per repeat unit; $1 \mathrm{~cm}$ cuvette; key indicates number of equivalents of Bipy per zinc porphyrin unit.

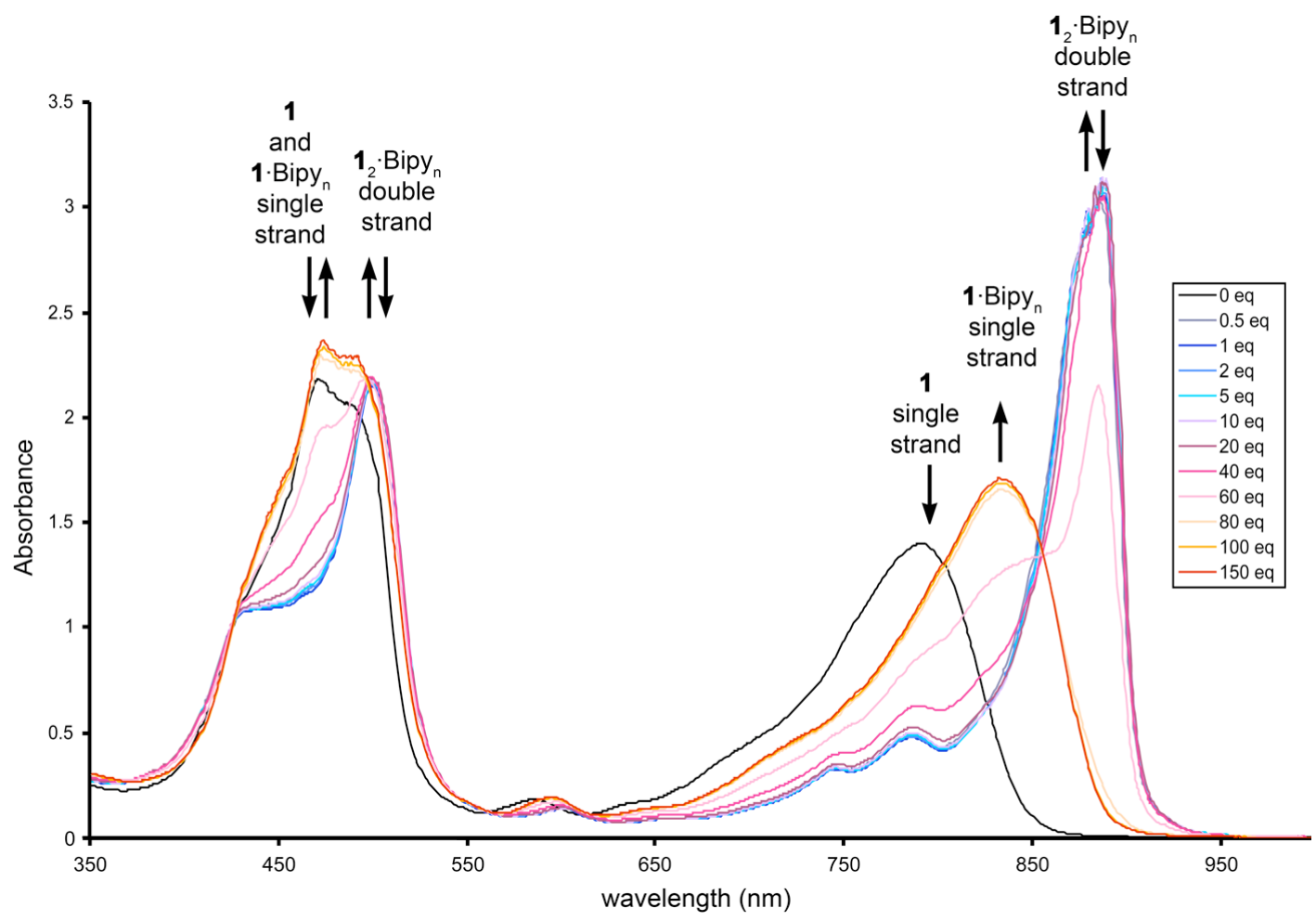

Figure S2: UV-vis-NIR Titration of Polymer 1 with Bipy in benzene; [1] $=0.25 \mathrm{mM}$ per repeat unit; $1 \mathrm{~mm}$ cuvette; key indicates number of equivalents of Bipy per zinc porphyrin unit. Note that this titration was carried out at the same concentration as the TRMC experiment and it shows that under these conditions the double-strand complex is stable with up to 60 equivalents of Bipy, corresponding to a Bipy concentration of $15 \mathrm{mM}$. 